\title{
1407 粒子法によるダム崩壊における衝撃圧力に関する研究
}

A Study of Impact Pressure by Particle Method for Dam Breaking

\section{日比茂幸（防衛大学校） 藪下和樹（防衛大学校）}

Shigeyuki HIBI, National Defense Academy, 1-10-20 Hashirimizu, Yokosuka, Kanagawa Kazuki YABUSHITA, National Defense Academy, 1-10-20 Hashirimizu, Yokosuka, Kanagawa

Key Words : Particle Method, MPS, Dam Breaking, Impact Pressure

\section{1. 緒言}

近年, 流体力学や構造力学の分野における数值シミュ レーションを行う方法として,メッシュレス法の一つと して粒子法が注目されている。粒子法は，流体力学の分 野においては, 流体が分離や合体をするなどして自由表面 が複雑に変化する問題など, 従来の方法では取り扱いの難 しいシミュレーションを行うことが出来るのが特徴であ る。MPS 法は，越塚ら吕によって開発された粒子法の一 つであり, 非圧縮性流れを解く解法として提案されたが, 最近では弾性体の問題にも応用されている。

一方，このような粒子法による流体挙動のシミュレー ション結果を, 実際の構造設計に用いようとする場合に は, 一般に流体の運動によって生じる圧力値が必要になる ことが多い。現状の計算機の性能を考えると, 3 次元問題 など大規模な計算を行う場合, 粒子数を十分に取ることが できないため, 相対的に少ない粒子数で解析対象をモデル 化することになる。このため相対的に少ない粒子数でモ デル化した場合でも，正確な圧力值を得られることが求 められる。しかし，流体の飛沫が壁面に衝突するような 場合, オリジナルの MPS 法では飛沫を表す水粒子が壁に 衝突したときに, 壁粒子が自由表面と判定されしまい圧力 が生じないため, 正確な圧力值を求めることができない という問題点がある。また, MPS 法から得られる圧力值 は, 不自然な振動をすることが知られている。このため, 末吉 · 内藤 ${ }^{2}$ や筆者ら ${ }^{3)}$ によってこの圧力值の振動を抑え る方法が提案されている。著者らが従来提案した方法は, ある粒子の周りに均一に他の粒子が存在するという仮定 に基づいていたが，実際の計算モデルでは，自由表面付 近の粒子や壁などの境界付近ではこの仮定が成り立たな い場合があると考えられる。そのため新たに少ない粒子 でも相対的に精度良く計算できる発散モデルを提案し6), 少ない粒子でも妥当な圧力が得られる事を確認している。 本研究ではこの方法をさらに検証するため, ダム崩壊の実 験を行い, シミュレーションから得られる壁面に生じる圧 力值との比較を行う。

\section{MPS 法と压力計算について}

\section{1 MPS 法について}

非圧縮性流体の解法である MPS 法では，連続の式と Navier-Stokes $(\mathrm{N}-\mathrm{S})$ 方程式を基礎方程式として考えてい る。離散化には, N-S 方程式中に現れる微分演算子であ るラプラシアンと勾配を重み関数などを使って, 粒子間 の相互作用に置き換えることで定式化を行っている。

粒子数密度 (Particle Number Density)

非圧縮性を表す密度一定の条件を, MPS 法では密度 $\rho$ そのものを使わずに, 次式で定義される時々刻々の粒子数 密度 $n_{i}$ が, 初期粒子配列の粒子数密度 $n^{0}$ になるように $\rho$ を $n_{i}$ に置き換えている。

$$
n_{i}=\sum_{j \neq i} w\left(r_{i j}\right)
$$

\section{自由表面の判定}

自由表面にある粒子の判定については, 式 (1) に従って 粒子数密度を計算すると, 対象としている粒子 $i$ が自由表 面付近にある場合とない場合を比べると，影響半径内に ある粒子数が相対的に少ないため, 粒子数密度の值も小さ くなる。この性質を利用して，次式を満たす場合に粒子 $i$ が自由表面上にあると判定する。

$$
n_{i} \leq \beta \times n^{0}
$$

ここで $\beta は$ 定数である。自由表面上にあると判定された粒 子は, 粒子 $i$ の持つ圧力を $P_{i}=0$ として与え, 次項の圧 力に関するポアソンの方程式に扔ける境界条件となる。

\section{MPS 法による圧力評価方法}

粒子数密度が一定值 $n^{0}$ になるという条件と陰的な $\mathrm{N}-\mathrm{S}$ 方程式の圧力項を組み合わせると以下のポアソン方程式 が得られる。この方程式を解くことにより, 流体中での圧 力が求められる。

$$
\nabla^{2} P_{i}=-\frac{\rho}{\Delta t^{2}} \frac{n_{i}-n^{0}}{n^{0}}
$$




\section{2 発散に関する離散式を導入した後処理と しての圧力評価方法}

発散を離散化する方法は, 近藤, 越塚や岡による弾 性体や構造物の解析に関する計算モデル4)や，Yoon, Koshizuka による流体解析の計算モデルとして ALE 法 的な粒子法の解析例の中で見られる ${ }^{5)}$ 。本研究では通常 のMPS 法によって計算・出力される時々刻々の各粒子が 持つ速度および位置情報などを元に, 後処理として圧力の ポアソンの方程式を, 次式のような発散の離散式を用いて 解き直すことで, より安定した圧力值を計算する事を提案 している。

$$
\nabla \cdot u_{i}^{(n)}=\frac{2}{n^{0}} \sum_{j \neq i}\left(\boldsymbol{u}_{j}^{(n-1)}-u_{i}^{(n-1)}\right) \cdot \frac{\boldsymbol{r}_{i j}}{r_{i j}^{2}} w\left(r_{i j}\right)(4)
$$

ここで注目すべき点は，粒子の位置に関しては時刻 $n$ の 值, 粒子の速度 $\boldsymbol{u}_{i}$ に関しては時刻 $n-1$ の值を用いて離 散化を行う点である。

\section{3. ダム崩壊の実験と数值計算との比較}

本計算方法の妥当性を検討するため, Fig.1に示すよう に, 水面高さ $\mathrm{H}=300 \mathrm{~mm}$ のダム崩壊の実験を行い, 得ら れた壁面の衝撃圧力值と数值計算の比較を行った。実験 時の圧力測定には，右壁面の底面 $40 \mathrm{~mm}$ の位置に取り付 けられた直径 8mm の圧カセンサーを用いた。

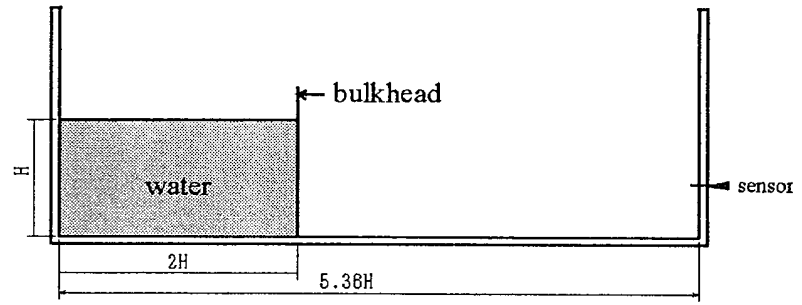

Fig. 1: Dimensions of Dam Breaking Experiment

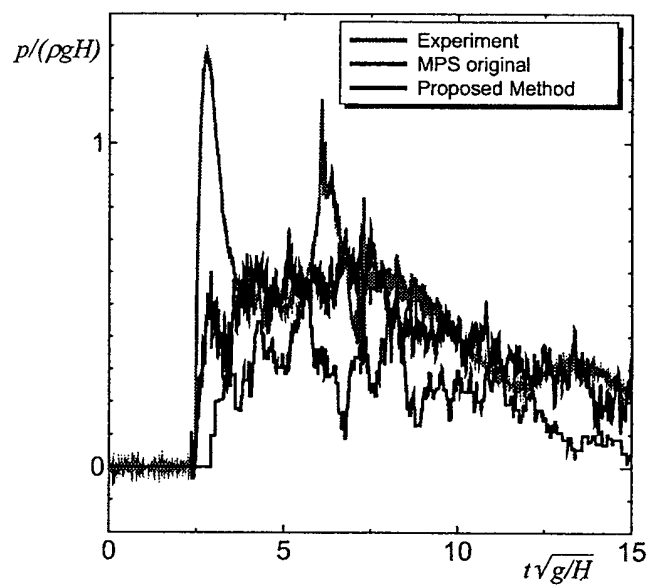

Fig. 2: Time history of pressure on the right side wall

Fig.2に，実験值とオリジナルの MPS 法および本計算 手法により解析した圧力の時刻歴を示す。なお数值計算 結果には, 圧力測定箇所に対応する壁粒子の圧力值に対し
て土 0.05 秒の時間平均を取ったものを示している。図よ り,オリジナルの MPS 法は実験值に比べて圧力值が少な 目になっていることがわかる。これは 水塊が壁面に衝突 後, 流塊が膜状に壁面を遡上する際に, オリジナルの MPS 法では自由表面すなわち圧力 0 とみなされる水粒子が多 く, 相対的に圧力計算に寄与する粒子が少なくなるためだ と考えられる。また全体にはオリジナルの MPS 法に比べ て本計算手法の方が実験值に近い変動をしているものの, 圧力のピーク值に関してはどちらも, うまく推定出来て いないことがわかる。

\section{4. 結言}

1. 本研究では, 速度の発散に関して提案した離散化式 を用いて, 少数の水粒子が壁面に衝突した場合でも 壁面に生じる圧力值を従来よりもより正確に求める ことができるかどうか, ダム崩壊の実験值と比較を 行い検討を行った。

2. 本計算手法の方がオリジナルの MPS 法よりも比較 的よい圧力の推定值を求めることが出来たが, ピー ク值に関しては今後の検討課題だと思われる。

謝辞 本研究で使われたプログラムは, 東京大学 越塚 誠一教授により公開されたソースコード1)を元に改造さ れたものである。著者らは越塚先生のオープンソースポ リシーに心から感謝の意を表すものである。

\section{参考文献}

1) 越塚誠一: 粒子法, 丸善, 2005.

2) Sueyoshi, M. and Naito, S. : A Numerical Study of Violent Free Surface Problems with Particle Method for Marine Engineering, Preprints of the 8th International Conference on Numerical Ship Hydrodynamics, Vol.2, 2003, pp.330-339.

3）日比茂幸, 藪下和樹：MPS 法の不自然な圧力振動 に関する研究，関西造船協会論文集，241 号，2004， pp.125-131.

4）近藤佳隆, 越塚誠一, 岡芳明 : 非均質粒子モデルによ る弾性体構造物計算における精度の向上, 計算工学 講演会論文集 Vol.5, 2000, pp.257-258.

5) Yoon, H. Y., Koshizuka, S. and Oka Y. : A ParticleGridless Hybrid Method for Incompressible Flows, Int. J. Numer. Methods in Fluids, 30, 1999, pp.407424

6) 日比茂幸, 數下和樹 : 改良 MPS 法による圧力評価に 関する研究, 防衛大学校理工学研究報告, 46 巻 1 号, 2008, pp.61-68. 